\title{
EDUCATION AND KNOWLEDGE-BASED ECONOMY
}

\author{
Prof. Metod Černetič, PhD \\ Faculty for Organizational Sciences in Kranj (Slovenia) \\ e-mail: mcgea@gmail.com, abc.medo@gmail.com
}

\begin{abstract}
With the term human capital different economists determine "stock of knowledge, which can be economically evaluated and has been captured by individuals." In the first place, these are qualifications, gained either in the system of qualification or either through professional experience. In the wider meaning this conception grasps numerous trumps, which can be carried into effect by individual in the marketplace and can be shown by employee as a potential sources of advantage: for example physical appearance, good manners, way of life and state of mind or even good medical condition. In such manner by the opinion of OECD human capital would unite "knowledge, qualifications, competence and individual characteristics, which relieve creation of personal, social and economic welfare." Conception of human capital is not entirely original, but it has achieved enormous success among international institutions and western governments, not only because it propose a strategy of permanent development as its advocates suggests, but because economical justifies education; what is in the eyes of decision makers only valid justification. Prevailing doctrine in pedagogy and education today has a focus in the theories of human capital. These theories, although full of ideological prejudices, reflect very real tendency of modern capitalism to mobilizing a far greater number of values to their double aspects of factors of production and merchandise.

Because of the pressures of global competition, in which knowledge becomes deciding element of competition, the cycle of knowledge rotate faster. More important becomes development of new products and services, their fast transfer to production or wider usage and simultaneous education and training of individuals in the way that they are able to include in the new product environment and use new products. Lisbon? If educational and research organizations, especially universities will try to stay important factor in the cycle of knowledge they will have to improve and innovate their educational technology and become more dynamic. In this moment they lose monopoly over creation and transfer of knowledge in the society of knowledge.

Lisbon's goals and strategy (2000) gives us the answers to the question how EU can be competitive in long term and at the same time preserve European model of life. That means a balance between economical, social and environmental goals.

Key words: strategy of development, human capital, education and research, cycle of knowledge, university and higher education, transfer of knowledge, competence.
\end{abstract}




\section{Introduction}

Prevailing doctrine in pedagogy and education today has a focus in the theories of human capital. These theories, although full of ideological prejudices, reflect very real tendency of modern capitalism to mobilizing a far greater number of values to their double aspects of factors of production and merchandise. Term of human capital is define by economists as a »stock of a knowledge, which can be economically evaluated and has been concurred by individuals. « In the first place, these are qualifications, gather either in the system of training or with professional experiences. In the broader meaning this concept include many trumps, which can be enforced by individual in the market of labor and shown to employee as potential sources of: for example appearance, good manners, way of thinking and life or health condition. According to OECD the idea of human capital unite »knowledge, qualifications, competences and individual characteristics that allay the creation of personal, social and economic welfare. « Conception of human capital is not entirely original, but it has achieved enormous success among international institutions and western governments, not only because it propose a strategy of permanent development as its advocates suggests, but because economical justifies education; what is in the eyes of decision makers only valid justification. Beside that this term as we will see has advantage because it shows decline of connection between school diploma and employment and justifies bigger selectiveness of employees in the time when meaning of informal components, especially the one of social origin, to define degree of employment of individual increases because of inflation of the title.

To truly understand the success of this term we have to start with some general considerations. With works of American economist Edward F. Denison in the sixties of 20th century it was possible to show, that economic development is not connected only with quantative growth of productive factors (capital and work) but also with the quality of labor force; and this quality was assumed to result from education (Denison, 1998, 22). If we consider that connection, continuation of growth could not be expected just from physical investments, and also no just from enlargement of extent of working force: investments have to be made in the new type of capital (OECD, 2001, 30). Idea of a human capital despite of opinion of some has not signified a revolution in standard economic theory but it has enabled a movement from former significance of expenses of education: they become investment and not consumption. New idea has widespread to different canals because of different interests; so in seventies of 20th centuries left parties and syndicalism has been took over this reflection. The reason has been a legitimacy that this could bring to state aspiration in the area of public education.

\section{Era of human capital}

Metaphor of »human capital « however lead to very impoverished vision of effects of »investment in value «, which is treated as source of improvement of productivity. Dangers of reduction are visible especially in ultraliberal version of this theory, advocated by other American economist. According to Becker (Laval, 2005, 
141) human capital is a personal good that bring an income to individual that carries this capital. This severely individualistic concept suits hypothesis of real liberal theory: individual is an owner of his own means, which he will try to increase in his life time with a purpose to increase his productivity, incomes and social advantages. In this sense we can see that there is nothing uninterested in extraction of human capital. This concept demands that selection of profession is one-dimensional: income is the only thing that matters when choosing a profession. In this was it neglects all representations of future, connected with present conditions, transportable values and possibilities that offer; it is also not conscious, that the relation of individual towards active life includes personal and collective history and also relations between social classes, ganders and different age groups.

\section{Ulitarism and choice of profession}

In ulitaristic concept of professional choice everything is managed by rational aspiration to gain additional income; this aspiration by itself however defines altitude of income that is expected from investments. Financing of the choice has to be depended form expected incomes and from the fact how useful and general are gained competences. If the costs of education are intended above all to creation of human capital, the question of who has to pay, who has to define content, who has to be master in this formation is raised. As regards to expect incomes the financing has to be divided between a state, company and individual. State of course can not loose its interest for education because there are some "positive exteriors « or effects favorable for all collective. But in the case that state has to take over some part of expenses for education, it has to create condition for individual to make rational choice and take over expenses that belongs to him. In the case that public authorities has to assure initial education - with regard to very big social profitability of investment to which they are devoted - they have to go to private funding, to families and companies. Especially in this era that is marked with budget limitation increase (OECD, 1997, 24).

It looks like that funding from different sources is the only rational way because in this way the larger part of costs are takeover by families and this part is proportional to personal advantages that are gained with that. So when OECD and World Bank call upon to funding from different sources or to co funding of education, they appeal to the logic of »educational profit«.

Social implications of this funding from different sources are far from being negligible. Analysis of costs and benefits should explain differences in investments in education. To the most talented students continuation of education is worth of money, because the investment in this case is very profitable; on the contrary, for the less talented students is better to drop out of school and to include in professional life as soon as possible. The theory of human capital is not equalitarian, although OECD and World Bank ascribe this theory as neutral. Becker (v Laval, 2005, 142) justifies educational inequality with rational calculation of individual: more talented students study faster and for limited price accumulate very profitable capital, but less talented have troubles to get to diploma and their price will not be repay with future incomes (OECD, 1997, 24). This logic works on the market of permanent qualify- 
cation, which has been - by some individuals - risen in the model for fundamental education and which most reliable effect is a production of inequality between those, who has the most from it, cadres and those who has the least, executive workers. From this point of view, cooperation between school and company is not inevitably democratic.

These ultrautaliristic concepts of education these days strongly influence to prevailing notions. It is fair to say that the fear that this concept will contribute to strengthen of education of different speed in which most profitable students are entitled to more investments as less competitive is real. Vast empirical literature shows that proportion between investment in qualification and level of payment is not that simple as liberal economists say. These concept of education as productive investment, which leads to individual income has a giant success and it is widely spread. Because of international and financial organizations this concept today is an ideological fundament of new world educational order.

\section{The changing of education and learning in 21st century}

The idea of learning society becomes really popular in the last few decades. There are many debates about how learning society should work and can be accomplished. Despite of fast economic and social development the gap, apathy and disappointment is getting bigger and bigger. There are not only big differences between developed and less developed countries but also between individual social groups in society or in a country.

All social, cultural, economic and other changes are almost paralyzing. The question of how to prepare all areas of society to more successful encounter with changes has been arisen. It became clearer that sole economical growth can not be accepted as ideal way of adjustment of material progress with equality and with a respect of human way of life; and it is also clear that new circumstances for more whole growth and development of all inhabitants are needed. In this process many tension will have to be bridged: between global and local, between common and individual, tradition and modern, between long term and short term approaches, between needed competitiveness and care for equal opportunities, between extraordinar development of human knowledge and human capability to capture it and between spiritual and material. All these tasks are asking for modernization of the idea of life long education and learning.

On the one side in the process of learning and education the individualization of process is stressed because it contributes to development of quality and potential of individual, to stimulation of personal growth, autonomy; on the other side richer individual knowledge stimulates the development of new opportunities for learning and education that is facilitate with modern technology. New, alternative possibilities influence to different comprehension of the role of education and learning and access of education to more people is a trend now. That is how the idea to create a learning society that is based on strategy of life long education. This strengthens up also a social dimension of education, which exceed previous by the class defined educational possibilities that come out from a social environment, economic position 
and other factors. Education and learning now become one of the main factors that can decrease alienation and inequality.

\section{Supplemention of education and research for knowledge society}

\subsection{Supplementation of information and knowledge with competence}

With a Lisbon declaration European Union has define a creation of knowledge society and on the knowledge based economy as its strategic orientation. Linear with this process a so-called Bologna process is happening in the field of higher education. With an inclusion into EU this becomes also a long term strategic orientation in Slovenia. In this text (Svetlik, 2005, 1-6) we are trying to expose that a lot has to be done in the area of education and research for creation of knowledge society. With this we mean above all supplementation; information and knowledge with the competences; explicit knowledge with a silent one; factographic and reflective with technical and social knowledge; fundamental with applicative and developped research; and individual phases of cycle of knowledge.

\subsection{Learning and knowledge}

Constructivist comprehension of knowledge enables its definition regarding to information. If we define information as data with meaning, is knowledge of individual information put into context. »Knowledge can be define as an information, as ability of interpretation or giving meaning to a data and information and as expressed wish to do that « (Beijerse, 1999). Definition of $\operatorname{OECD}(1997,33)$ is similar: Knowledge is a cumulative stock of cognitive skills and information of any individual, family or community that can be used in personal or social situations.

Learning economy (Lundvall 2000, v Svetlik 2005, 7) gives advantage to fast results that can be commercially used. In this circumstances gaining of competences and skills, which assure success in pursuit of own goals and goals of organizations becomes important. Gaining of competences is fundamentally different from usual comprehension of learning as acquisition and contextualization of information. It is fair to say that competences upgrade knowledge. They are capability of knowledge use. "In education there is an aspiration for development of competences instead of learning of written knowledge. The knowledge is not so much important as its usage (Euridyce, 2002)." If this is true, the succession from data to knowledge should be complete with competences. We believe that competences present special knowledge: knowledge about use of knowledge.

Stated findings present challenges for education. In the other words the question is what is fundamental task of education: is this a mediation of increasing number of information that are usually better presented by media, world web, libraries and similar than teachers or this is a help with choice and understanding of information, with their contextualization and interpretation in a new knowledge. Later demands creation of new learning situations as seminar, project work and case studies. It demands examine of knowledge and not only recollection of row data as 
dates, names, formulas and similar. Pretentiousness of pedagogical process to develop also competences is increasing.
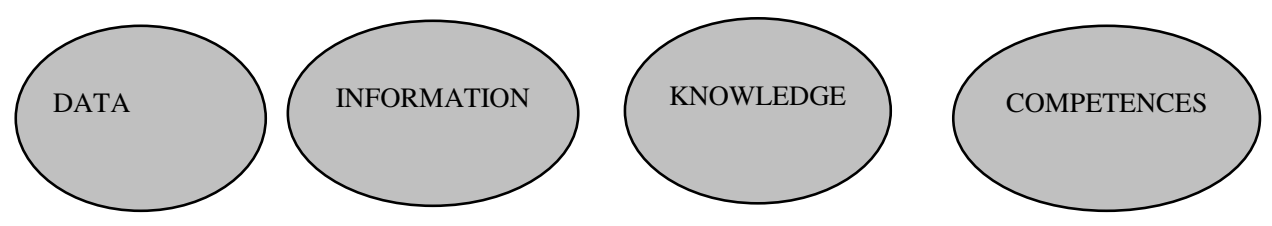
201)

Picture 1: From data to competences (Source: Svetlik, 2005 v Černetič 2007,

This demand practices, tests, contact with real action and life environment. And through this concept of key competences as information communication literacy, social skills, learning of learning, methods of time and decision making management, business and similar this fond of general knowledge is supplementing on all levels of education in Europe (Euidyce, 2002; Tacitkey, 2001).

\section{To balance a cycle of knowledge}

On of the most citied concepts when dealing with a society of knowledge is cycle of knowledge. Between most representative is a model of OECD (2001) that is constructed from creation, transfer and use of knowledge.

Cycle of knowledge is rotated on many different levels. On the level of social institutions as creators of knowledge we most often recognize research and development institutions, as transfer of knowledge we recognize educational institutions and as a users of knowledge product organizations. But the cycle of knowledge is often resolved also on the level of organization. When this knowledge is used in the processes of work is often created with technological improvements or in the special development units. We also provide a transfer of knowledge from an environment when we employ new cadre of send them to trainings. The transfer of knowledge - especially the silent one - to the new ones or between the members of organization flows also in direct working processes, in working groups, on internal seminars and informal. Similar resolution as for organizations can be made for individuals. In the process of learning, in accordance with constructivist understanding - individuals create knowledge and then use it in the working processes and differrent situations in life and transfer them to co-workers, family members and others. Because of the pressures of global competition, in which knowledge becomes deciding element of competition, the cycle of knowledge rotate faster. More important becomes development of new products and services, their fast transfer to production or wider usage and simultaneous education and training of individuals in the way that they are able to include in the new product environment and use new products. 


\section{The cycle of knowledge is often resolved also on the level of organization}

More then ever before new questions arise:

- Is the cycle of knowledge concluded? It is logical to point out to weak links between research development and educational institutions on one side and product organizations on the other side. Later do not get enough of new knowledge and adequate cadre. The first may not research real problems and educate the right cadres.

- Is the cycle of knowledge fast enough? Traditional institutional division of labor between research, education and production becomes clumsy because of reaction time research, education and production organization need for reaction to each other. Before production manages to get a new knowledge through new diplomats, competition already overtakes it.

- How permanent is knowledge? Logical conclusion is that less and less. Therefore the emphasis on life long education (EC, 2000) and learning organizations (Senge, 1994) are logical. Sooner or later the question of reasonableness of extension of initial education in which on the beginning gathered knowledge loses its relevant will arise.

Organizations tend toward creation, transfer and usage of their own knowledge. Experts in organizations have two skills: creation and interpretation of new ideas from external sources and transfer of knowledge to others. When transferred collective knowledge is often bigger then sum of individual knowledge (Birly, Daly, 2002 v Černetič 2006, 212). Learning organization with design of organizational culture that stimulates employees to critical thinking and to take a risk with new ideas and with valuation of their contributions create conditions, in which individuals in able to learn permanently and distribute their knowledge to others. In this way they stimulate the process of learning and creation of special organizational knowledge, which is partly loaded in the head of members of organization and partly expressed in organizational innovation, technological documentations, rules of conduct and decision making.

Because of all this traditional division of labor between research, educational and production organizations is weakening. Product organization, also Slovenian, stimulate their own cycles of knowledge and try to gain the knowledge directly from researchers. If educational and research organizations, especially universities will try to stay important factor in the cycle of knowledge they will have to improve and innovate their educational technology and become more dynamic. In this moment they lose monopoly over creation and transfer of knowledge in the society of knowledge.

\section{Directives for education and research}

If educational and research organizations, especially universities will try to stay important factor in the cycle of knowledge they will have to improve and in- 
novate their educational technology and become more dynamic. In this moment they lose monopoly over creation and transfer of knowledge in the society of knowledge.

Formatting society of knowledge and on the knowledge based economy will therefore demand from educational and research institution next things (Svetlik, 2005 v Černetič 2006, 206):

- inclusion of experts from practice and a creation of programs and inclusion of teachers and researchers in development and practical work in organizations that employ diplomats and use new knowledge,

- for novelties open and flexible programs of education and research,

- integrated programs of education, which will upgrade factographic and reflective knowledge with competences or technical and social knowledge,

- modernization of educational technology or pedagogical process with emphasis on creation of for work and life relevant learning subjects in which students will play much more active role,

- international exchange of students, teachers and researchers,

- development of integrated research that include fundamental, applicative and developing research, advisory work and education,

- evaluation of educational and research institution and individuals based on how much knowledge do they create (scientific articles, books, citations), how much they are able to pass on others (diplomats, textbooks, expertise) and how much this knowledge is used (patents, research and seminar orders, employment of diplomats).

For creation of economy and society in which we have life long education and that give us super sum effects in the process of gaining, creation, transfer and usage of knowledge, we need to assure (beside technical) also social conditions. One of the fundamental conditions is relationships of mutual trust. Without them individual in or out of organizations will not uncover their silent knowledge that could be used without any bonus to them or even against them Maki in Jarvenpaa (2001 v Černetič, 2006, 45) found that excess to explicit knowledge depend on confidentiality of data, excess to silent knowledge depend on mutual trust.

The second extremely important condition for creation of society of knowledge is according to Lundvall (2000 v Černetič, 2006, 243), social cohesion or control over social differentiation without which the whole project is under question. According to Lundvall in the times of old social agreement social, ecological and policy of money tribute had a role of post festive shock absorber of trouble of those, which could prevent failure in economical competition of individual. Put different, those who has trouble to learn are in the knowledge society in advance condemn to social exclusion. Without relatively proportional distribution of knowledge and work there is no knowledge society. Like Lundvall decide: without social capital is impossible to create intellectual capital.

\section{Conclusion}

Certainly we have to be careful about a credulous that leads to illusion about »new economy«. It is not necessary that the market of pedagogy and learning is as 
profitable as everybody thinks. All economic models enforced in e-learning today did not prove to be pertinent. Companies that cooperate can me disappointed over relative autonomy of teachers and dynamics of professional practice. The use of common free pages (print), practice for teachers and students to exchange pedagogical sources - that could disappointed many hopes, unless someone could persuade teachers to connect with pages that they have to pay - and that is the only way to exceed a threshold of profitability, expected from a new techniques. But this is not possible in this moment. It is from here that campaigns of persuasion and waking of guilt, that perform pressure in behalf of spending for new services and mass consumption of materials come from. Despite this ideological flood many American and Canadian works already cracked a myth about internet and information science as miracle solution for school problems (but because of that Europe with her inferior complex, so characteristic for her elite, hasn't stopped to »discover America «.)

In reality considerable economic interests that change learning and education into market and school in factories of competences are more important.

The extremely important condition for creation of society of knowledge is according to Lundvall (2000 v Černetič, 2006, 243), social cohesion or control over social differentiation without which the whole project is under question. According to Lundvall in the times of old social agreement social, ecological and policy of money tribute had a role of post festive shock absorber of trouble of those, which could prevent failure in economical competition of individual. Put different, those who has trouble to learn are in the knowledge society in advance condemn to social exclusion. Without relatively proportional distribution of knowledge and work there is no knowledge society. Like Lundvall decide: without social capital is impossible to create intellectual capital.

\section{Sources and References}

Černetič, M. Dimensions of Learning Organisation and Knowledge Society. Journal od Education.Tainan Università, Taiwan 2008.

Černetič, M. Knowledge and learning - knowledge society, Faculty for Organizational Sciences, 2008.

Černetič, M. Management in sociologija organizacij. Moderna organizacija, Kranj, 2007.

Černetič, M.: Development and globalisation - from the economic and sociological points of view. V: Černetič, M. (ur.), Mušanović, M. (ur.), Dečman Dobrnjič, O. (ur.). Comparative pedagogy : selected topics. [Maribor]: Faculty of Education; [Kranj]: Faculty of Organizational Sciences; Rijeka: Croatian Future Society, 11-18, 2006.

Černetič, M.: Knowledge and education - between the labour market and human resources. V: Sapia-Drewiniag, E. (ur.), Jasinski, Z., (ur.), Bednarczyk, H., (ur.). Adult education at the beginning of the 21 st century : theoretical and practical contexts : kontektsy teoretyczne $i$ praktyczne: Theorie und Praxis]. Opole; Radom; Bonn: University of Opole [etc.], str. 283-294, 2002.

Černetič, M.: Knowledge and education - management of development $=$ Znanje $\mathrm{i}$ obrazovanje - upravljanje razvojem. Informatologia (Zagreb), vol. 36, no. 1, 15-20, 2003.

Černetič, M.: Management ekonomike izobraževanja, Moderna organizacija, Kranj, 2006. 
Černetič, M.: Society of knowledge is cycle of knowledge. Collected papers III. National interdisplinary scientific professional conference, Subotica, Serbia, p. 327-335, 2010.

Drucker, P.: The Post-capitalist Society, Butterworth, Oxford, 1993.

Economic Commission for Europe (2005) Economic Survey of Europe, 1/2005, UN, Geneva. Education

ERT (1997): Investing in Knowledge, The Integration of Technology in European

Human Resources and New Tehnology: Main Trends and Issues. CERI/CW/89.01. V: Education and Economy in a Changing Society. OECD, Pariz 1989.

Laval, C.: Šola ni podjetje, ZPS, Sophia, Ljubljana, 2005.

Svetlik, I.: Avtonomija in integracija univerze, Slovenska smer, Ljubljana, 1995.

Svetlik, I.: Doplolnjevanje izobraževanja in raziskovanja za družbo znanja, Tipkopis, 11.4.05, DS, Ljubljana, 2005.

Ziman, J.: An Introduction to Science Studies, the Philosophical and Social Aspects of Science and Technology, Cambridge University Press, Cambridge, 1984.

Metodički obzori 7(2012)3

Prethodno priopćenje

UDK: 37:33]:001

Received: 17. 2. 2011.

\title{
IZOBRAŽEVANJE IN NA ZNANJU TEMELJEČE GOSPODARSTVO
}

Prof. dr. sc. Metod Černetič

Fakultet organizacijskih znanosti, Kranj (Slovenia)

e-mail: mcgea@gmail.com, abc.medo@gmail.com

\begin{abstract}
Povzetek
Razvoj človeških virov je zadnja desetletja prevladujoča pedagoška doktrina. Slovenija je bila v mednarodnih raziskavah (Human Resources Report od 1998 do 2001) vključena $\mathrm{v}$ proučevanje človeških virov. S tako imenovanim indeksom HDI (poprečno število let šolanja, zdravje in bruto družbeni proizvod na glavo prebivalca). Te mednarodne primerjave za Slovenijo niso bile laskave.

Drucker P. (1993) je v devetdesetih letih 20. stoletja je trdil, da vstopamo v družbo znanja, kjer osnovni ekonomski vir ne bodo le ekonomski kapital, naravni viri in delovna sila, temveč znanje in da bodo nosilci znanja odigrali ključno vlogo. Uspešnejša bodo tista podjetja, ki bodo bolje upravljala z znanjem in znanje znala poiskati, zavarovati, porazdeliti po podjetju, izkoristiti, itd. Odločilno vlogo pri razvoju Slovenije ima razvoj človeških virov (Černetič 2002, 478).V današnjem času se poudarjajo lastnosti, ki niso neposredno povezane s kapitalom kot materialno dobrino, ki je, mimogrede, vladal predolgo. Še vedno igra denar vodilno vlogo, vendar se vse bolj uveljavlja tudi znanje in z njim povezane izkušnje, talent in ustvarjalnost, ki veljajo za vrlino oz. bogastvo, ki bo zaznamovalo prihodnost.
\end{abstract}


Pomen človeškega razvojnega dejavnika narašča skladno z vlogo, ki jo imajo pri globalni konkurenčnosti znanje, inovativnost, ustvarjalno izkoriščanje in obvladovanje informacij, organizacija in vodenje ter drugi kakovostni dejavniki. Narašča pomen infrastrukture in institucij, ki omogočajo mobilnost in prilagodljivost delovne sile ter njeno vseživljenjsko učenje. Spreminja se tudi vsebina človeškega razvojnega dejavnika. Poleg individualnih lastnosti, kot sta izobraženost in zdravje posameznika (človeški kapital), narašča tudi pomen socialnih odnosov, ki se oblikujejo v interakcijah med ljudmi (socialni kapital). $\mathrm{Na}$ vprašanja $\mathrm{v}$ članku je EU poskušala na institucionalni ravni odgovoriti $\mathrm{z}$ t.i. Bolonjsko reformo visoko šolskega in univerzitetnega izobraževanja. Ta reforma je trenutno v t.i. postsocialističnih novih članicah EU praviloma neuspešna. EU ne zagotavlja dosega t.i. Lizbonskih ciljev. Krog znanja - cycle of knowledge- ni zaokrožen.

Ključne besede: strategije razvoja, človeški kapital, izobraževanje in raziskovanje, krog znanja, visokošolsko in univerzitetno izobraževanje, na znanju temelječa družba, kcompetence in prenos znanja 